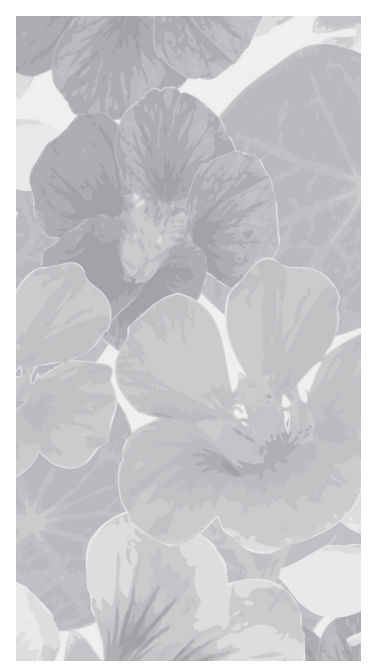

\section{Kształcenie kosmetologiczne}

\section{Education in cosmetology}

Jacek Arct

Wyższa Szkoła Zawodowa Kosmetyki i Pielęgnacji Zdrowia, Warszawa

Estetol Med Kosmetol 2012; 2(1): 7-10

DOI: http://dx.doi.org/10.14320/EMK.2012.001

English version of this article starts on page 10

Key words: cosmetology, higher education

Słowa kluczowe: kosmetologia, szkolnictwo wyższe
Podstawą rozwoju każdej dziedziny ludzkiej działalności jest odpowiednie kształcenie specjalistów. W jednakowym stopniu dotyczy to wszystkich obszarów funkcjonowania nowoczesnego społeczeństwa - produkcji surowców i dóbr materialnych, tworzenia i funkcjonowania infrastruktury, zarządzania, szeroko pojętych usług, itd. Bez odpowiednio wykształconej kadry żadna z tych dziedzin nie może prawidłowo funkcjonować i rozwijać się. Jednocześnie niezwykle szybki postęp w zakresie nauk stosowanych wymusza zmianę profilu kształcenia, maleje zapotrzebowanie na wąskich specjalistów, coraz częściej wymagania wobec wiedzy formalnej zastępowane są profilem umiejętności zawodowych. Tego rodzaju podejście do kształcenia zawodowego znalazło swój wyraz w znowelizowanej w ubiegłym roku ustawie Prawo o szkolnictwie wyższym, stawiającej system Krajowych Ram Kwalifikacji ponad formalnymi wymaganiami dla treści programowych poszczególnych kierunków. Na tle tych trendów sytuacja w zakresie kształcenia na kierunku kosmetologia budzi szereg obaw. Studia tego typu mają dość długą tradycję w USA i krajach Ameryki Łacińskiej. W Europie istnieją przede wszystkim w Niemczech i we Francji jako kierunki stricte zawodowe, kształcące na I poziomie studiów wyższych. Zakres kształcenia jest tam bardzo szeroki i zależnie od uczelni przygotowuje specjalistów o różnym profilu, generalną tendencją jest jednak coraz szerszy program kształcenia. Można tu wyróżnić dwa podstawowe kierunki: absolwenci są przygotowywani do pracy w obszarze beauty biznesu albo z ukierunkowaniem na zaplecze przemysłu kosmetycznego albo na pogranicze medycyny estetycznej. Ten drugi kierunek jest oczywiście możliwy jedynie tam, gdzie istnieją odpowiednie regulacje prawne umożliwiające kosmetologom wykonywanie zabiegów inwazyjnych. Profil absolwentów tych uczelni zdecydowanie różni się od profilu zawodowego kosmetyczek, które uzyskują wykształcenie typu rzemieślniczego, umożliwiające jedynie wykonywanie zabiegów kosmetycznych w odpowiednich placówkach usługowych.
W Polsce kosmetologia jest kierunkiem nowym, o ciągle nieuregulowanym statusie, wprowadzona na listę kształcenia wyższego nieco ponad 10 lat temu, od trzech lat może być formalnie realizowana jako studia II stopnia (magisterskie). Gwałtowny rozwój ponad 60 uczelni prowadzących w naszym kraju ten kierunek wynika z dwóch czynników. Pierwszym jest związany z bogaceniem się społeczeństwa, modą i czynnikami demograficznymi rozwój beauty biznesu. Nie bez znaczenia jest tu ciągle rosnąca w naszym kraju produkcja kosmetyków - pod tym względem zajmujemy już szóste miejsce w Europie, tuż za „wielką piątką” europejskich potęg gospodarczych. Drugi czynnik wydaje się mieć charakter socjologiczny i jest związany z ogólnym dążeniem do zdobywania wykształcenia wyższego jako miernika pozycji społecznej. Świadczy o tym wysoki udział czynnych zawodowo kosmetyczek wśród studentek kosmetologii, zwłaszcza na studiach niestacjonarnych. Ten niekontrolowany rozwój, przy stosunkowo słabych kontaktach z zaawansowanymi ośrodkami zagranicznymi doprowadził do wytworzenia całkowicie błędnych wyobrażeń na temat profilu wykształcenia kosmetologów jako „lepiej wykształconych kosmetyczek". Pogląd taki jest całkowicie nieuzasadniony merytorycznie, deprecjonuje zawód kosmetologa i przyczynił się do powstania stereotypów skutecznie hamujących rozwój tej dziedziny. To jemu właśnie zawdzięczamy pejoratywne określenia w rodzaju „magister od klepania” czy „licencjat z kręcenia kremu”, często nadużywane, zwłaszcza w prominentnych środowiskach naukowych. Dla pełnego zrozumienia pojęcia zawodu kosmetologa konieczne jest całościowe spojrzenie na tzw. beauty biznes. Jeżeli przyjąć za punkt wyjścia, że kosmetologia obejmuje wiedzę o kosmetykach i ich stosowaniu (a są to pojęcia nierozłączne, obszary wzajemnie w pełni zależne od siebie) to całościowy obraz branży jawi się jako niezwykle złożona struktura sterowana z jednej strony rozwojem nauk podstawowych, takich jak biologia skóry, medycyna, farmakologia, chemia, fizyka oraz technologii będących owocami tego rozwoju, z drugiej zaś czynnikami makro- i mikroekonomicznymi pojmowanymi nie tylko jako zysk ze 
sprzedaży surowców, produktów i usług, ale także jako siła nabywcza społeczeństwa, w którym hierarchia potrzeb (w tym potrzeby realizacji określonego typu urody) jest pochodną stopnia zamożności oraz mechanizmów socjologicznych kreujących wzorce (moda) i nisze marketingowe. Rolą kosmetologa, obok bezpośredniego udziału w realizacji podstawowych zadań branży - produkcji i dystrybucji kosmetyków oraz organizacji i prowadzeniu sfery usługowej, jest funkcja pośrednika między opisanymi wyżej czynnikami sterującymi i mechanizmami wykonawczymi. Stawia go to w bardzo trudnej sytuacji, często narzucana jest mu rola decyzyjna na styku bardzo odległych dziedzin wiedzy stosowanej. Sprostać tym zadaniom może tylko dzięki odpowiedniemu, multidyscyplinarnemu wykształceniu.

Musimy wyznaczyć wyraźną linię oddzielającą kosmetologię od medycyny estetycznej. Kosmetolog i lekarz medycyny estetycznej lub dermatolog powinni ze sobą współpracować, daje to znacznie lepsze rezultaty (również ekonomiczne) niż bezsensowna konkurencja, wzajemne naruszanie kompetencji, nie zawsze precyzyjnie uregulowanych prawem. Współpraca taka wymaga określonej wiedzy obydwu stron, ciągłej wymiany poglądów, a polem do tego powinna być wspólna edukacja zainteresowanych przedstawicieli obu grup zawodowych. Kosmetolog musi rozumieć zarówno zabiegi medyczne związane z zachowaniem i korektą wad urody, jak i patologię skóry i jej przydatków. Z kolei dermatolodzy oraz lekarze medycyny estetycznej powinni znać zasady podstawowych zabiegów kosmetycznych oraz dysponować określonym zasobem wiedzy na temat właściwości i zastosowań kosmetyków. Drugi biegun wiedzy kosmetologa stanowią zagadnienia związane z produkcją kosmetyków. Jest to tradycyjnie domena chemików, farmaceutów i biotechnologów. Obszar kompetencji jest tu znacznie trudniejszy do sprecyzowania niż na styku z medycyną, zarówno ze względu na brak regulacji prawnych, jak i na znacznie szerszy zakres zagadnień łączących obydwie dziedziny. Z całą pewnością szereg elementów chemii kosmetycznej, szczególnie z zakresu technologii, chemii analitycznej czy wytwarzania surowców wykracza poza wykształcenie kosmetologa, wystarczy, by kosmetolog znał je w zakresie pozwalającym na komunikację ze specjalistami w tych dziedzinach. Jednocześnie wiele zagadnień należy do obszarów wspólnych, na przykład właściwości form kosmetycznych, elementy receptury kosmetycznej, właściwości i działanie surowców, zagadnienia biodostępności składników czynnych, metody oceny skuteczności i bezpieczeństwa gotowych wyrobów itp. Ze względu na szersze wykształcenie podstawowe i kierunkowe kosmetolog może tu niekiedy mieć przewagę nad chemikiem, a nawet farmaceutą lub toksykologiem. Jego wykształcenie powinno zapewnić znajomość opisanych zagadnień na poziomie umożliwiającym swobodne porozumiewanie się z odpowiednimi specjalistami.
Trzeci biegun multidyscyplinarnej wiedzy kosmetologa zlokalizowany jest na styku produktu z odbiorcą. Ten obszar określa się ogólnie mianem marketingu, który decyduje o sukcesie ekonomicznym stanowiącym siłę napędową dla całej branży. Tworzenie skutecznego marketingu i reklamy wymaga w równym stopniu zrozumienia potrzeb grupy docelowej, jak i cech użytkowych produktu. Jedynie kosmetolog potrafi przekazać specjalistom od reklamy czy marketingu informacje o produkcie w zrozumiałej dla nich formie. I nie ma znaczenia czy chodzi tu o sprzedaż produktu kosmetycznego, czy o zachęcenie klienta do skorzystania z określonych usług kosmetycznych. Jedynie kosmetolog zna właściwości użytkowe kosmetyku, zalety zabiegu kosmetycznego lub SPA w stopniu wystarczającym, aby dostarczyć specjaliście od marketingu lub reklamy wiedzę umożliwiającą celowe i skuteczne działanie, kreowanie odpowiedniej komunikacji z konsumentem lub eksplorację nowych nisz rynkowych. I znów jak w poprzednio opisanych obszarach granicznych, krytycznym elementem staje się problem komunikacji i wzajemnego zrozumienia. Kosmetolog musi zatem znać podstawy marketingu w stopniu umożliwiającym tę komunikację, co w praktyce oznacza co najmniej podstawowe wykształcenie w tym zakresie.

Opisane wyżej graniczne obszary wiedzy są istotnymi wyznacznikami zakresu kształcenia dla kierunku kosmetologia. Określają zakres wykształcenia podstawowego, który obejmuje wiedzę począwszy od elementów fizyki, chemii i biochemii, poprzez podstawy biologii, anatomię i fizjologię po najważniejsze podstawy nauk medycznych - farmakologię, toksykologię, dermatologię, immunologię i medycynę ogólną. Równocześnie kosmetolog musi dysponować wiedzą zawodową obejmującą zarówno teorię i praktykę zabiegów kosmetycznych, jak i „kosmetykologię”, czyli wiedzę o składzie i działaniu kosmetyków. Uzupełnieniem tej wiedzy musi być kierunkowa wiedza z zakresu budowy i stosowania aparatury kosmetycznej, wiedza o surowcach i zasadach recepturowania kosmetyków, znajomość zasad prawnych, metod oceny skuteczności i bezpieczeństwa stosowania produktów kosmetycznych, znajomość zasad marketingu surowców, produktów i usług kosmetycznych oraz umiejętności organizacji i prowadzenia przedsiębiorstw beauty biznesu. Jest zrozumiałe, że przedstawiony zakres wiedzy kosmetologa nie jest możliwy do osiągnięcia w ciągu krótkich, trwających 6 semestrów studiów licencjackich. Te powinny być nastawione przede wszystkim na przedmioty podstawowe, a ponadto zawodowe obejmujące teorię i praktykę zabiegów kosmetycznych i „kosmetykologię”. Studia II stopnia - magisterskie muszą rozszerzać wiadomości nabyte na pierwszym stopniu, przede wszystkim w zakresie interdyscyplinarnej wiedzy kierunkowej związanej z medycyną estetyczną, recepturowaniem i oceną skuteczności działania i bezpieczeństwem 
stosowania kosmetyków oraz elementami marketingu produktów i usług kosmetycznych. W moim przekonaniu wprowadzenie w życie opisanych wyżej zasad kształcenia kosmetologów nie będzie procesem łatwym. Jedną z podstawowych trudności jest brak odpowiedniej kadry nauczającej, zwłaszcza w zakresie „kosmetykologii”. Dotyczy to nie tylko chemii kosmetycznej pojmowanej jako wiedza o działaniu i recepturowaniu kosmetyków, ale przede wszystkim nowoczesnych metod oceny działania i bezpieczeństwa użycia produktów. Podobna sytuacja panuje w dziedzinach wiedzy związanych z dystrybucją - marketingu, reklamie, psychologii i wiedzy o technikach sprzedaży. Kadrę nauczycieli w tym zakresie możemy pozyskiwać z dwóch źródeł. Pierwszym są firmy produkujące i dystrybuujące kosmetyki, które w wielu przypadkach dysponują odpowiednio wykształconymi pracownikami. Pierwszym krokiem w tym kierunku są zmiany w ustawie Prawo o szkolnictwie wyższym dopuszczające zatrudnianie na uczelniach fachowców nie spełniających klasycznych kryteriów akademickich. Przeszkodą jest niechęć przedsiębiorstw do dzielenia się z innymi wiedzą pracowników, w których wykształcenie zaangażowano firmowe środki. Jest to podejście niezbyt rozsądne, w krajach rozwiniętych angażowanie pracowników firm w procesy kształcenia i działalność organizacji edukacyjnych jest popierane i postrzegane za element marketingu korporacyjnego. Drugim źródłem może być wspieranie (przede wszystkim finansowe) kształcenia kadry akademickiej w ramach studiów podyplomowych, zarówno w ośrodkach krajowych, jak i zagranicznych, np. na podyplomowych studiach Chemia Kosmetyczna w WSZKiPZ lub na Wolnym Uniwersytecie w Brukseli.

Kolejnym czynnikiem wpływającym negatywnie na jakość kształcenia jest obawa uczelni (w większości szkół niepublicznych) przed utratą kandydatów na studia na skutek wprowadzenia bardziej zaawansowanego programu, zwłaszcza obejmującego elementy chemii kosmetycznej. Niechęć tę potęguje niski poziom nauczania chemii i fizyki w szkołach - stała bolączka naszego systemu kształcenia. W rezultacie edukację akademicką trzeba zaczynać od podstaw chemii ogólnej i organicznej, co zwykle napotyka na opór ze strony słuchaczy. Braki wykształcenia ze szkoły średniej nie pozwalają studentom zrozumieć treści przedmiotów związanych z chemią kosmetyczną, biochemią, farmakologią, a nawet fizjologią skóry. Skutkuje to zakłóceniem całego procesu kształcenia, w rezultacie poziom wiedzy absolwentów studiów licencjackich jest często w tym zakresie żenująco niski. Odrębnym źródłem nieporozumień przy określaniu profilu zawodowego kosmetologa jest brak jednoznacznej granicy prawnej pomiędzy kosmetologią i medycyną estetyczną. Jest to temat kontrowersyjny, stanowiący zarzewie wielu konfliktów i utrudniający współpracę pomiędzy obydwoma, tak sobie przecież bliskimi grupami zawodowymi. Przyczyną nieporozumień jest - i to trzeba sobie powiedzieć wprost - rentowność spornych zabiegów. Zabiegi estetyczne „z pogranicza”, takie jak np. mezoterapia, modelowanie tkanek kwasem hialuronowym lub polimlekowym czy wstrzykiwanie toksyny botulinowej należą do najbardziej zyskownych ze względu nie tylko na wysokie marże, ale także ogromny popyt napędzany modą. Sytuację utrudnia brak prawnego uregulowania statusu medycyny estetycznej jako specjalizacji lekarskiej. Konieczne są tu jednoznaczne rozstrzygnięcia oparte na zasadzie, że tylko w przypadku medycznych zawodów regulowanych możliwe jest stosowanie technik związanych z bezpośrednim ryzykiem zdrowotnym dla pacjenta. Rozstrzygnięcia takie powinny być efektem rzeczowej dyskusji pomiędzy kompetentnymi przedstawicielami środowiska kosmetologów i lekarzy medycyny estetycznej. Jeżeli we wzajemnym zacietrzewieniu i krótkowzrocznej walce o bezpośrednie zyski do takiej dyskusji nie dojdzie, sprawa zostanie rozstrzygnięta bez udziału fachowców, ze szkodą dla obydwu stron.

Podsumowując, o przyszłości polskiej kosmetologii w równym stopniu zadecyduje rynek pracy oraz samo środowisko. Nowoczesny rynek - zarówno polski, jak i zagraniczny potrzebuje wszechstronnie wykształconych kosmetologów, zdolnych do podjęcia pracy we wszystkich obszarach beauty biznesu. Jeżeli przy istniejącym potencjale akademickim sprostamy temu zapotrzebowaniu przez odpowiednie podniesienie poziomu kształcenia, mamy szansę w tym zakresie stać się wiodącym krajem Unii Europejskiej. Alternatywą jest masowa produkcja licencjatów i magistrów pracujących przez całe życie przy łóżkach zabiegowych w krajowych i zagranicznych gabinetach i ośrodkach piękności. Zapotrzebowanie na takie ograniczone wykształcenie wydaje się maleć, tym bardziej, że jest ono stosunkowo kosztowne. Świadczy o tym chociażby zmniejszający się na tym kierunku nabór na studia niestacjonarne, co stanowi zagrożenie dla wielu założonych dużym nakładem sił i środków uczelni. Pamiętajmy, że uczelnia, której absolwenci mogą łatwo znaleźć pracę nie tylko przy łóżku w salonie kosmetycznym, ale także w całym obszarze beauty biznesu będzie w dłuższej perspektywie wygrywać konkurencję i zyskuje szansę utrzymania się na rynku edukacyjnym przyszłości.

\section{Finansowanie i konflikt interesów}

Pierwotna wersja tego artykułu ukazała się w czasopiśmie Cosmetology Today, nr 1/2011. Wykorzystano za zgodą wydawcy. 


\section{Adres do korespondencji}

prof. WSZKiPZ dr inż. Jacek Arct Wyższa Szkoła Zawodowa Kosmetyki

i Pielęgnacji Zdrowia

ul. Podwale 13, 00-252 Warszawa

E-mail: j.arct@wszkipz.pl
Data złożenia: 5.01 .2012

Data akceptacji: 10.03 .2012

Data aktualizacji: 30.11 .2012

\section{Education in cosmetology}

\section{Kształcenie kosmetologiczne}

Jacek Arct

Academy of Cosmetics and Health Care, Warsaw

Estetol Med Kosmetol 2012; 2(1): 10-13

DOI: http://dx.doi.org/10.14320/EMK.2012.002

Wersja polska tego artykułu na stronie 7

Key words: cosmetology, higher education

Slowa kluczowe: kosmetologia, szkolnictwo wyższe

Development in each field of human activity is based on suitable specialist training. It applies to all areas in a modern society - production of raw materials and goods, building and maintenance of infrastructure, management, services, etc. None of these areas can function properly and develop without personnel with suitable education. At the same time, the extremely fast progress in applied sciences requires changes in the educational profile. Demand for narrow-educated specialists is decreasing and requirements for formal knowledge are frequently replaced by professional skills. The new approach to professional education is expressed in the recent amendments to the Higher Education Act. The act puts the system of the National Qualification Framework above formal specialization requirements reflected by study curricula. Taking into consideration these trends, educational strategies applied in cosmetology arouse a range of doubts. Tertiary education in cosmetology has quite a long tradition in the USA and Latin America. European institutions teaching cosmetology, located predominantly in Germany and France, provide strictly vocational training at the first level of higher education. A wide range of courses is offered, aimed at preparing different specialists, depending on the profile of an institution. Nevertheless, there is a general tendency to offer wider and wider curricula. Two main directions could be distinguished in this respect: the first prepares students for working within the beauty business, whereas the second is oriented rather towards the cosmetics industry or aesthetic medicine. The latter studies are obviously feasible only in countries with legislation allowing cosmetologists to carry out invasive treatments. The professional profiles of graduates from tertiary educational institutions significantly differ from the profile of beauticians, whose qualification allow them only to perform cosmetic treatments in beauty salons.

Cosmetology is relatively new to Poland. It was introduced into the higher education system some ten years ago, for the last three years it could be also formally continued at the second level of higher education (studies with acquisition of the Master of Science degree). In Poland, two factors have stimulates the rapid development of cosmetology studies, which are now offered by more than 60 tertiary education institutions. The first one is related to the increasing wealth of Polish society, and the resultant fashion for and expansion of beauty business. Not unimportant is the constantly growing production of cosmetics in Poland, which occupies at present the sixth position in Europe, just after Europe's five biggest economies. It seems that the second factor is sociological in nature and related to peoples' aspiration for acquiring a higher education as a means of confirming one's social position. It is manifested by a relatively large number of beauticians among cosmetology students, especially those enrolled in part-time programmes.

Such uncontrolled development and lack of contacts with more advanced foreign education institutions created the space for the misconception of a cosmetologist's 